\title{
ДОСВІД ПОДОЛАННЯ ЗЛОЧИННОСТІ СЕРЕД НЕПОВНОЛІТНІХ У РОКИ ДРУГОЇ СВІТОВОЇ ВІЙНИ 1942-1945
}

\author{
Ольга Силка \\ Київський міжнародний університет \\ Київ, Україна \\ ORCID: 0000-0002-4694-8310
}

\section{THE EXPERIENCE OF OVERCOMING CRIME AMONG JUVENILES DURING THE SECOND WORLD WAR 1942-1945}

\begin{abstract}
Summary: The article examines the identity of a juvenile offender, his social and psychological characteristics. The social and economic causes of crimes committed by children are determined. Examples of unemployment of minors and violations of public order are given. The main measures of the Soviet government in the field of crime prevention among homeless children, search for children, creation of an agency network, ideological work are revealed. Statistics on the number and types of crimes committed by minors, as well as their examples are provided. A comparison of juvenile delinquency in the western and eastern regions of the USSR and its features. In particular, a conclusion was made about the effectiveness of the authorities in preventing and overcoming juvenile delinquency in 1942-1945.
\end{abstract}

Key words: children, homelessness, crime, minors, preventive measures, search

Дитяча злочинність відрізняється від злочинності дорослих тим, що має здебільшого груповий характер. Половина злочинів неповнолітніх здійснюються у складі групи, а щодо окремих ситуацій цей показник може бути навіть вищим. Наприклад, 70-80\% крадіжок, хуліганства, грабежів, згвалтувань та вимагання можуть вчинятися у складі групи. Злочинні групи неповнолітніх зазвичай нечисленні (2-3 особи), без стійкої організації та створюються на невеликий строк і можуть швидко бути викритими правоохоронними органами.

Груповий характер злочинності неповнолітніх можна пояснити психологічними та соціальними передумовами підліткового об'єднання. Страх перед знущаннями з боку старших, прихильність 3 боку однолітків, почуття неповноцінності, самотності. А у роки війни, ще й звичайний інстинкт вижити, знайти хоч якийсь соціум, який би замінював сім'ю'.

1 С. Бабенко, Причини та умови злочинності неповнолітніх, Донецьк 2009, с. 38. 
Маємо взяти до уваги той факт, що в 1942-1945 роках сім’ї були неповними, адже чоловіки пішли на фронт або загинули. Неналежне функціонування інституту сім’ї призводило до бездоглядності, а згодом і до злочинності. Додавалося в знаки ще й матеріальне неблагополуччя, спричинене масштабною розрухою через військові дії.

Існували випадки, коли діти, через брак виховання й уваги 3 боку батьків, втікали 3 дому та вели антисуспільний спосіб життя. Як наприклад, Віктор Михайлович Рассоха 3 1938-го року народження ніде не навчався, систематично здійснював втечі від батьків та вів бродячий спосіб життя. Його батько - член КП(б)У, який працював на заводі ім. Фрунзе у місті Костянтинівці. Сім'я була матеріально забезпечена, але батько вихованням сина не займався. Найчастіше бездоглядність спричиняв тяжкий матеріальний стан родин. Загибель чоловіка або перебування його в лавах радянської армії змушували жінку посилено й тяжко працювати в установах та на виробництвах. Діти таких батьків часто не були охоплені дитячими таборами, садками та іншими виховними установами, за ними, зазвичай, наглядали старші брати, сестри або бабусі, які, нерідко не забезпечували необхідного догляду та виховання. Це призводило до небажаних наслідків - жебракування, торгівлі на базарах, безцільне блукання вулицями, де залишалося ще багато неприбраних боєприпасів та нерозмінованих полів. Як згадує очевидець подій Володимир Іларіонович Дубков, мешканець міста Сніжне Донецької області: “На полях погибали. Василенко ногу оторвало, Ткаченко стала инвалидом...”. Дитяча незайнятість інколи призводила до величезних матеріальних збитків. Так, у полі радгоспу Єнакіївського району "Червоний профінтерн" згоріла скирта соломи, яка важила 65 тонн. Збиток складав дві тисячі карбованців. Слідство виявило, що п’ять учнів молодших класів селища Октябрський Горлівського району були винні в загоранні. Вони вийшли в поле, щоб постріляти із самопалів, а один учень - Іван Сібелев, 1938 року народження, в присутності інших школярів кинув запалений сірник у скирту, стверджуючи, що солома не займеться ${ }^{2}$.

Як видно з наведених даних, значна кількість дітей порушували громадський порядок через відсутність належної виховної роботи з боку батьків. Поряд з тим, необхідно зазначити, що велику кількість дітей затримували за вуличну торгівлю та жебракування, на що їх штовхали самі батьки. Так, у Краматорському районі робітник районного споживчого союзу Іван Янкевич мав сина та дочку. Сім'я проживала в хороших матеріальних умовах, але син все одно приторговував на вулиці, за що й був затриманий. Громадянка Ганна Дерміткіна, що мешкала в тому ж районі

\footnotetext{
2 Н. Касьянова, Боротьба з безпритульністю та бездоглядністю в перші післявоєнні роки (на прикладі Донбасу), Донецьк 2011, с. 114
} 
Сталінської області та працювала в донорському магазині, постійно відправляла власну дочку на базар продавати хліб ${ }^{3}$. Безсумнівно, в таких випадках батьками керувало не бажання наживи. Важкість післявоєнного суспільства диктувала мобілізацію всіх імовірних шляхів для забезпечення нормального рівня життя.

3 цього випливає, що вкрай незадовільні умови мешкання знедолених дітей, дефіцит належної уваги у справі виховання дітей з боку шкіл, опікунів та батьків ставав причиною їх масових втеч. Опинившись на вулиці, діти, рано чи пізно, потрапляли під вплив злочинних груп чи осіб, адже необхідність задоволення першочергових фізичних потреб, штовхала дитину на шлях скоєння правопорушень.

Через брак уваги до питання виховання дітей з боку батьків та шкіл, багато неповнолітніх залишалися поза системою шкільної освіти, через що мали місце серйозні проступки та карні злочини серед дітей.

Утворилося замкнуте коло - виявлених дітей повертали батькам або до виховних закладів, а через деякий час, вони знов потрапляли на вулиці. Навіть їдальню міста Горлівки міського комітету партії обікрали маленькі діти. Злочинців не судили, бо їм було по 8-10 років, а повернули батькам, у свою чергу останніх притягували до адміністративної відповідальності. Найчастіше це були штрафи або попередження та догани. Проте самі діти зазвичай залишалися поза системою державного покарання, а, значить, і не відчували провини ${ }^{4}$.

Мало місце підштовхування дітей до кримінальних злочинів зі сторони дорослих. Так, наприклад, у дитячому будинку № 2 міста Одеси були здійснені 3 крадіжки дитячого одягу, мануфактури та інших речей вихованцями цього ж будинку. Крадені речі збувались громадянкою Іриною Мазуровою, яка платила їм по 100 рублів за метр мануфактури. Неповнолітні особи, які підштовхували дітей на шлях злочинності й бездоглядності, не несли особливого покарання, їх лише викликали для бесіди, тоді, як дорослих за такі ж дії штрафували й притягували до кримінальної відповідальності. Всього за І-й квартал 1945 року притягнуто 151 людина із них: оштрафовано 142 людини на суму більш як 20000 рублів, до кримінальної відповідальності притягнуто 9 чоловік, попереджено 750 чоловік5.

\footnotetext{
3 Центральний державний архів громадськиї об'єднань України, Фонд Р-2, опис 7, Справа. 1548. Матеріали про стан і роботу дитячих будинків, патронатів, приймальників та про боротьбу з безпритульністю, бездоглядністю дітей в Українській РСР після звільнення територій України від німецьких окупантів. 1944 р., арк. 53.

4 Н. Касьянова, Боротьба з безпритульністю та бездоглядністю в перші післявоєнні роки (на прикладі Донбасу), Донецьк 2011, с. 154.

5 Центральний державний архів громадськиї об'єднань України, Фонд.1, опис 23, Справа, 2411. Докладные записки, справки о состоянии и работе по борьбе детской беспризорностью в областях Украины. Работа детских домов. 1945, арк. 26.
} 
Ситуація ускладнювалася й збільшенням кількості безпритульних, які не мали засобів для існування, що спонукало їх до хуліганських дій. Найбільш поширеним видом злочину була крадіжка.

Більшість крадіжок у пасажирів, розкрадання з вагонів, кишенькових крадіжок і навіть грабежів здійснювалося також підлітками. Це підтверджують свідчення громадянина Петра Буркова, який заявив у Котовський відділ залізничної міліції про пограбування його двома підлітками, котрі забрали рейсові картки, зняли 3 нього бушлат та черевики. Грабіжники були затримані в результаті проведених заходів. Ними виявилися Іван Кузнєцов і Володимир Рощев. Обидва народилися в 1928 році. У них знайшли й повернули потерпілому пограбоване майно

Так, 10 вересня 1945 року о 16 годині за два кілометри від семафора станції Чернігів Південно-Західної залізниці група неповнолітніх злочинців у кількості шести осіб напала на пастуха I. I. Тамашина, якого роздягнули і забрали весь одяг. Вжитими заходами розшуку було затримано Миколу Ренклада, Володимира Тюліна, які втекли 3 дитприймальника НКВС міста Чернігова, речі повернено потерпілому, а безбатченків відправлено до трудової колонії НКВС 7 .

Наказом НКВС СРСР № 001359 від 5 серпня 1943 р. було запроваджено Інструкиію про боротьбу з дитячою злочинністю і хуліганством, якою вся ця “боротьба" покладалася на Головне управління міліції (ГУМ) НКВС СРСР, Управління транспортної міліції ГУМ НКВС СРСР, а на місцях - на управління міліції НКВС республік, країв та областей, транспортні і водні відділи, відділення (групи) міліції по боротьбі з дитячою безпритульністю, бездоглядністю і злочинністю, які мали право, як і приймальниками розподільники, комісії по боротьбі з дитячою безпритульністю і бездоглядністю при районних (міських) виконавчих комітетах Рад депутатів трудящих направляти неповнолітніх правопорушників у ДТВК. Постановою РНК СРСР № 659 від 15 червня 1943 р. Про посилення заходів боротьби з дитячою безпритульністю, бездоглядністю і хуліганством та наказом Наркомату юстиції СРСР від 19 червня 1943 p. для неповнолітніх, яким не виповнилося 16 років, за скоєні ними дрібні злочини (дрібне хуліганство, дрібні крадіжки та інші незначні правопорушення) створювалися трудові виховні колонії, в яких перевиховувалися ці “важкі" підлітки без винесення судового вироку.

Доцільно зауважити, що проблема негативної поведінки неповнолітніх як безпритульних, так і бездоглядних дітей була настільки серйоз-

Там само, арк. 15.

А. Шевченко, Боротьба співробітників транспортної міліщії України з дитячою безпритульністю та бездоглядністю (1941-1945рр.), "Наука. Релігія. Суспільство" 2003, № 1, c. 167. 
ною, що вона стала предметом для обговорення на засіданні РНК УРСР під головуванням голови уряду Микити Хрущова в листопаді 1944 р. Зокрема, було проаналізовано стан дисципліни серед учнів київських шкіл та прийнято спільну постанову ЦК КП(б)У і РНК УРСР, яка визначала заходи $з$ профілактики правопорушень серед неповнолітніх. За цим документом рекомендувалося справи на неповнолітніх порушників норм суспільної поведінки одразу передавати органам НКВС, а судовим органам не зупинятися перед найсуворішими репресивними заходами ${ }^{8}$.

Було організовано спеціальні групи, з метою покращення боротьби 3 дитячою злочинністю в органах прокуратури. Визначено прокурорів і слідчих які спеціалізувалися виключно на дитячій злочинності.

Загалом, до суду за вчинені злочини було передано 11715 підлітків у віці від 12 до 16 років, із них: у 1944 р. - 3975 підлітків, у 1945 р. - 5946 підлітків, у І кварталі 1946 р. - 1794 підлітки9.

Кількість засуджених неповнолітніх по областях УРСР

\begin{tabular}{|l|r|r|}
\hline \multirow{2}{*}{\multicolumn{1}{|c|}{ Область }} & \multicolumn{2}{|c|}{ Кількість засуджених } \\
\cline { 2 - 3 } & 1944 рік & I квартал 1945 року \\
\hline Вінницька & 50 & 56 \\
\hline Ворошиловградська & 623 & 148 \\
\hline Волинська & 1 & 18 \\
\hline Дніпропетровська & 186 & 154 \\
\hline Драгобичська & 1 & 2 \\
\hline Житомирська & 68 & 23 \\
\hline Запоріжська & 156 & 52 \\
\hline Ізмайлівська & - & 14 \\
\hline Киїська & 94 & 81 \\
\hline Кіровоградська & 49 & 38 \\
\hline Кам’янець-Подільська & 40 & 75 \\
\hline Львівська & 3 & 12 \\
\hline Миколаївська & 72 & 18 \\
\hline Одеська & 33 & 72 \\
\hline Полтавська & 146 & 57 \\
\hline Ровенська & 36 & 23 \\
\hline Сумська & 111 & 43 \\
\hline Станиславська & - & - \\
\hline
\end{tabular}

8 Центральний державний архів громадськиї об'єднань України, Фонд.1, Опис 23, Справа, 1392. Докладные записки, информации о мероприятиях по борьбе с детской беспризорностью в Украинской ССР. 1945, арк. 158, 161.

9 Центральний державний архів громадськиї об'єднань України, Фонд.1, Опис 72, Спрова. 132. Докладные записки, справки, сведения и переписка по вопросам борьбы с детской беспризорностью, о работе детских домов, 1944 р., арк. 38. 


\begin{tabular}{|l|c|c|}
\hline \multirow{2}{*}{\multicolumn{1}{|c|}{ Область }} & \multicolumn{2}{|c|}{ Кількість засуджених } \\
\cline { 2 - 3 } & 1944 рік & І квартал 1945 року \\
\hline Сталінська & 917 & 365 \\
\hline Тернопільська & 4 & 4 \\
\hline Харківська & 292 & 28 \\
\hline Херсонська & 48 & 30 \\
\hline Чернігівська & 74 & 11 \\
\hline Черновицька & 36 & \\
\hline
\end{tabular}

Як свідчить аналіз даних, найбільш криміногенною була ситуація із безпритульними та бездоглядними підлітками в індустріальних областях та великих містах (Сталінська, Ворошиловградська, Харківська, Дніпропетровська, Запорізька, Київська, Одеська області та їх обласні центри), що давали 64,7\% злочинів від скоєних неповнолітніми в Україні. У західних областях сумарна злочинність неповнолітніх становили $8,3 \%$, а решта $27 \%$ злочинів приходилося на інші області ${ }^{10}$.

Таким чином, низький рівень злочинності у західних областях можна пояснити не лише аграрним характером цих областей, меншою чисельністю населення, а й тим побутово-звичаєвим укладом, який формувався під впливом, батьків, Церкви, громадськості впродовж століть. Крім того, необхідно зазначити, що значна частка злочинів була скоєна власне “мандруючими” неповнолітніми, які приїжджали у західні області з інших регіонів України та Російської Федерації. Тому власне частка скоєних злочинів неповнолітніми безпритульними і бездоглядними дітьми, вихідцями із місцевого населення не перевищувала $3 \%$.

Кількість неповнолітніх поданих до суду у II півріччі 1945 р. уже зменшилася на 26,8\% порівняно з І півріччям. Зокрема, убивств зменшилося на 36,9\%, грабежів - на 9,9\%, хуліганських проявів - на 19,2\%, крадіжок - на 2,9\%, серед інших злочинів відбулося зменшення на 27,6\%. 3 усіх злочинів у II півріччі зросла лише на 2,7\% кількість злочинів, пов'язаних із нанесенням тілесних пошкоджень ${ }^{11}$.

Найбільше засуджених неповнолітніх було у великих промислових містах, що свідчить про їх концентрацію у таких та пояснюється відновленням промисловості, яка тоді була вкрай необхідною. Після визволення відбуваються великі хвилі міграції. Люди їдуть на відбудову промис-

\footnotetext{
10 О. Андрухів, Історико-правовий досвід застосування карально-профілактичних заходів для подолання злочинності серед неповнолітніх, "Науково-інформаційний вісник Івано-Франківського університету права імені Короля Данила Галицького” 2017, № 4(16), с. 32.

11 О. Андрухів, Боротьба з дитячою безпритульністю в західних областях Украӥнської Радянської Сочіалістичної республіки в умовах звільнення від нацистських окупантів, “Науковий вісник гуманітарного університету” 2018, № 31, с. 26.
} 
ловості з усього Радянського Союзу. Невиключно, що під час переїздів багато дітей губилося. Батьки іноді самі залишали дітей на вокзалах, бо не маючи змоги їх прогодувати, бажали кращої долі дитині в дитячому будинку або в іншій виховній установі.

У 1946 р. прослідковується тенденція до зростання злочинності серед безпритульних дітей, особливо в східних і південних УРСР, що певною мірою було пов'язано із голодом, зумовленим в основному природними катаклізмами.

Розшук дітей був важливою складовою в боротьбі з бездоглядністю безпритульністю та злочинністю. Відомо, що під час війни органи міліції проводили роботу з розшуку людей, які зникли. Центральне довідкове бюро діяло у складі паспортного відділу НКВС СРСР. При ньому, за заявами громадян, працював спеціальний довідковій відділ з розшуку дітей.

Такі аналогічні структури мали всі підрозділи міліції від республіканських до обласних. Ці органи оперували даними про місцезнаходження дітей, що знаходилися в дитячих приймальниках-розподільниках і були направлені на патронат або до дитячих установ, а також тих, які були працевлаштовані. Вказані дані надходили від народних комісаріатів соціального забезпечення, освіти, здоров'я, управління трудових резервів та дитячих приймальників-розподільників НКВС до довідково-адресних столів. Робота відділів з розшуку дітей мала вагомі результати та цінувалася населенням, про що свідчили численні подяки громадян, що присилалися на адресу працівників міліції.

Наприклад, від громадянки Ф.І. Пантелійчук, жительки міста Старобільська Ворошиловградської області. Вона під час евакуації втратила зв'язок із власними дітьми, Ідою та Володимиром, які знаходились у дитячому будинку Ізмаїльської області. Дитячий будинок під час війни був евакуйований, і працівник довідково-адресного столу виявив дітей у Медвенському районі Курської області ${ }^{12}$.

Привертає увагу оперативна робота із протидії дитячій злочинності, яка передбачала залучення агентури для обслуговування дитячих домів, шкіл, місць концентрації неповнолітніх злочинців та притонів. При цьому до агентурної роботи залучалися й самі підлітки. У таємному донесенні начальникам НКВС СРСР зазначалось, що агентурна мережа розвинута слабко. Органи міліції невміло підходять до вербування, несерйозно й бездумно виховують агентуру із неповнолітніх. У результаті цього неповнолітні агенти відмовляються працювати або швидко розсекречуються. Дуже часто взагалі недооцінюють агентурну мережу, тому ухиляють-

12 Центральний державний архів громадськиї об'єднань України, Фонд.1, Опис 72, Справа. 132. Докладные записки, справки, сведения и переписка по вопросам борьбы с детской беспризорностью, о работе детских домов, 1944 р., арк. 80. 
ся від вербування. Особливо наголошувалося на необхідності створення агентурної мережі з середовища неповнолітніх згідно з наказом НКМВС СРСР № 001359 від 15 серпня 1943 року. Основну увагу звернути на виявлення дорослих, які залучають в злочинну діяльність неповнолітніх і на розкладання злочинних формувань серед дітей. У необхідних випадках потрібно було організувати обізнану мережу в школах, училищах, гуртожитках підлітків. Направляти роботу цієї мережі на виявлення причин, які сприяли виникненню злочинності учнів та втеч зі шкіл ${ }^{13}$.

Боротьба народу висунула ряд вимог, які змінили навчально-виховну роботу. Особлива увага стала приділятись патріотичному вихованню дітей. Змінився характер викладання літератури, історії, географії. Юнаки та дівчата повинні були надихатись образами молодих героїв - Зої Космодем'янської, Лізи Чайкіної, Саші Чекалина, Миколи Гастелло та інших.

Ідеальним образом радянської дитини був образ піонера. Він існував не тільки в офіційній пропаганді, але й в свідомості більшості дітей. Піонерами хотіли стати всі. Піонерські організації мали великий вплив на виховання і розвиток дітей. Вони намагались допомагати фронту, відвідували будинки учасників військових дій, допомагали по господарству сім'ям, де не було чоловіків (кололи дрова, носили воду, доглядали за маленькими дітьми). Відвідували будинки інвалідів війни, пенсіонерів, також допомагали їм по господарству. Піонери організовували дозвілля: вигадували сценарії для вистав, проводили свята та спортивні змагання, мотивували вчитись.

Піонер поставав як ідеальна радянська дитина, який не мав шкідливих звичок, полюбляв працю, заправляв постіль. Безумовно, реальний піонер міг відрізнятись від ідеалу, але більшість намагались наблизитись до нього. У роки війни цей образ по зрозумілим причинам ще більше ідеалізується, тому ідеального піонера більшість сприймали як героя 3 якого треба брати приклад. Діти, які вступали в піонери, пишалися цим званням.

У навчальних закладах доволі активно велась пропагандистська і агітаційна діяльність. Діти активно слухали розповіді про героїв війни, слідкували за воєнними діями, малювали карти просування військ, відмічали на картах взяті і звільнені міста, прослуховували курси патріотичного виховання. Діти були оточені гаслами про допомогу фронту, які були написані в стилістиці військового часу. Основний пропагандистський вплив на населення в ході війни відбувався через пресу та радіо ${ }^{14}$.

13 Державний архів Міністерства внутрішніх справ України по Вінницькій області, Фонд 1, Справа 56, Приказы, циркуляры СССР за 1943 г., 569 арк.

14 М. Геллер, Машина и винтики. История формирования советского человека, Москва 1994, с. 336. 
Також варто згадати про таке явище, як некваліфікованість педагогічних кадрів цього періоду. На 15 грудня 1944 року в довідках ЦДАВОВ натрапляємо на інформацію, що керівними кадрами дитячі будинки в основному укомплектовані задовільно в загальній кількості 352 директори 3 вищою та 337 чоловік середньою освітою, 3 педстажем більше 5 років 267 , але в Західних областях деяку частину керівних кадрів потрібно замінити ${ }^{15}$.

У спеціальних дитячих будинках з 66 директорів з вищою освітою 32 та середньою 34, педстаж більше 5 років мали 61 чоловік. Народним комісаріатом освіти УРСР встановив практику затвердження директорів дитячих будинків з особистим їх викликом до Наркомосвіти. 3 кінця жовтня по 15 грудня 1944 року затверджено уже 108 директорів будинків, у тому числі 52 директори спеціальних дитбудинків.

Також проведені курси в листопаді-грудні 1944 року в 12 областях України обласні місячні курси для вихователів дитячих будинків за навчальним планом та по програмі розробленій НКО УРСР.

Можливо, проблема недостатнього догляду за дітьми виникала ще й через те, що вузи та педагогічні школи не готували фахівців-вихователів для дітей дитбудинків. Кадри вихователів комплектують з учителів та інших осіб з певною освітою. Але ж такі кадри не знають специфіки виховної роботи в дитбудинках - і тому їм доводилося в процесі роботи набувати потрібні знання ${ }^{16}$.

Висновки. Бездоглядність, яка виникла в досліджуваний період, змушувала дітей об'єднуватися в групи, щоб вижити. Спочатку заняттям таких підлітків могло бути бродяжництво, жебрацтво, пустощі, а згодом це переростало в злочинність. Більшість злочинів неповнолітніх здійснювалися через залучення дітей, які безцільно проводили час на вулицях, вокзалах, підвалах й інших місцях, до злочинних груп.

Для попередження цих явищ органами міліції проводився розшук дітей. Ці органи оперували даними про місцезнаходження дітей, що знаходилися в дитячих приймальниках-розподільниках і були направлені на патронат або до дитячих установ, а також тих, які були працевлаштовані. Також залучалась агентурна мережа. 3 дітьми проводилась ідеологічна робота, яка була налаштована на патріотичне виховання. Недоліком системи стала некваліфікованість робочих кадрів.

\footnotetext{
15 Н. Касьянова, Боротьба з безпритульністю та бездоглядністю в перші післявоєнні роки (на прикладі Донбасу) Донецьк 2011, с. 155

16 Центральний державний архів громадськиї об'єднань України, Фонд. Р-2, Опис 7 Справа. 1548. Матеріали про стан і роботу дитячих будинків, патронатів, приймальників та про боротьбу з безпритульністю, бездоглядністю дітей в Українській РСР після звільнення територій України від німецьких окупантів. 1944 р., арк. 79.
} 
Правопорушення вчинялися переважно осиротілими дітьми через тяжкий матеріальний стан, заради виживання. Найбільш поширеним видом злочину була крадіжка. У 2-ій половині 1945 р. злочинність неповнолітніх зменшується, а вже в 1946 знову збільшується. Це говорить про те, що система заходів вирішувала проблему тільки на деякий час, але глобально питання не вирішувала, а значить мала прогалини.

\section{БІБЛІОГРАФІЯ}

Andrukhiv Oleg. 2017. İstoriko-pravovij dosvìd zastosuvannâ karal'no-profilaktičnih zahodìv dlâ podolannâ zločinnostì sered nepovnolitnih. "Naukovo-ìnformacìjnij vìsnik İvano-Frankìvs'kogo unìversitetu prava ìmenì Korolâ Danila Galic'kogo" №4 (16): 29-33. [Андрухів Олег. 2017. Історико-правовий досвід застосування карально-профілактичних заходів для подолання злочинності серед неповнолітніх. "Науково-інформаційний вісник Івано-Франківського університету права імені Короля Данила Галицького” № 4 (16): 29-33].

Andrukhiv Oleg. 2018. Borot'ba z ditâčô̂ bezpritul'nistû v zahìdnih oblastâh Ukraïns'koï Radâns'koï Socialističnoï respubliki v umovah zvil'nennâ vìd nacists'kih okupantìv. "Naukovij vìsnik gumanitarnogo unìversitetu” № 31: 25-31. [Андрухів Олег. 2018. Боротьба з дитячою безпритульністю в західних областях Украӥнської Радянської Соціалістичної республіки в умовах звільнення від наџистських окупантів. “Науковий вісник гуманітарного університету” № 31: 25-31].

Central'nij deržavnij arhìv gromads'kiï ob êdnan' Ukraïni Fond 1. Opis 23 Sprava 2411. Dokladnye zapiski, spravki o sostoânii i rabote po bor'be detskoj besprizornost'û v oblastâh Ukrainy. Rabota detskih domov. 1945, 118 ark. [Центральний державний архів громадськиї об'єднань України Фонд 1. Опис 23 Справа 2411. Докладные записки, справки о состоянии и работе по борьбе детской беспризорностью в областях Украины. Работа детских домов. 1945, 118 арк.].

Central'nij deržavnij arhìv gromads'kiï ob êdnan' Ukraïni. Fond 1. Opis 72, Sprava 132. Dokladnye zapiski, spravki, svedeniâ i perepiska po voprosam bor'by s detskoj besprizornost'û, o rabote detskih domov. 1944 r. 265 ark. [Центральний державний архів громадськиї об'єднань України. Фонд 1. Опис 72, Справа 132. Докладные записки, справки, сведения и переписка по вопросам борьбы с детской беспризорностью, о работе детских домов. 1944 р. 265 арк.].

Central'nij deržavnij arhìv gromads'kiï ob 'êdnan' Ukraïni. Fond 1.Opis 23, Sprava 1392. Dokladnye zapiski, informacii o meropriâtiâh po bor'be s detskoj besprizornost'û v Ukrainskoj SSR. 1945. 32 ark. [Центральний державний архів громадськиї об’єднань України. Фонд 1.Опис 23, Справа 1392. Докладные записки, информации о мероприятиях по борьбе с детской беспризорностью в Украинской ССР. 1945. 32 арк.].

Central'nij deržavnij arhìv gromads'kiï ob 'êdnan' Ukraïni. Fond R-2. Opis. 7, Sprava 1548. Materìali pro stan ì robotu ditâčih budinkìv, patronatìv, prijmal'nikìv ta pro borot'bu $\mathrm{z}$ bezpritul'nìstû, bezdoglâdnìstû dìtej $\mathrm{v}$ Ukraïns'kìj RSR pìslâ zvìl'nennâ teritorìj Ukraïni vìd nìmec'kih okupantìv. 1944 r., 520 ark. [Центральний державний apхів громадськиї об'єднань України. Фонд Р-2. Опис. 7, Справа 1548. Матеріали про стан і роботу дитячих будинків, патронатів, приймальників та про боротьбу 
з безпритульністю, бездоглядністю дітей в Українській РСР після звільнення територій України від німецьких окупантів. 1944 р., 520 арк.].

Deržavnij arhìv Mìnìsterstva vnutrišnìh sprav Ukraïni po Vìnnic'kìj oblastì Fond 1. Sprava.

56. Prikazy, cirkulâry SSSR za 1943 g. 569 ark. [Державний архів Міністерства внутрішніх справ України по Вінницькій області Фонд 1. Справа. 56. Приказы, циркуляры СССР за 1943 г. 569 арк.].

Mihail Geller. 1994. Mašina i vintiki. Istoriâ formirovaniâ sovetskogo čeloveka. Moskva: MIK [Михаил Геллер. 1994. Машина и винтики. История формирования советского человека. Москва: МИК].

Nataliâ Kas'ânova. 2011. Borot'ba z bezpritul'nistû ta bezdoglâdnìstû v peršì pìslâvoênni roki (na prikladi Donbasu). Donec'k: Donbas [Наталія Касьянова. 2011. Боротьба з безпритульністю та бездоглядністю в перші післявоєнні роки (на прикладі Донбасу). Донецьк: Донбас].

Sergìj Babenko. 2009. Pričini ta umovi zločinnostì nepovnolitnih. Donec'k: Donec'kij ûridičnij ìnstitut Lugans'kogo deržavnogo unìversitetu vnutrì̌nìh sprav ìm. E.O. Dìdorenka [Сергій Бабенко. 2009. Причини та умови злочинності неповнолітніх. Донецьк: Донецький юридичний інститут Луганського державного університету внутрішніх справ ім. Е.О. Дідоренка].

Ševčenko Andrìj. 2003. Borot'ba spivrobitnikìv transportnoï milìciï Ukraïni z ditâčô̂ bezpritul'nistû ta bezdoglâdnistû (1941-1945 rr.). "Nauka ì osvìta" № 1: 165-169 [Шевченко Андрій. 2003. Боротьба співробітників транспортної міліиії України з дитячою безпритульністю та бездоглядністю (1941-1945рр.). "Наука і освіта” № 1: 165-169].

\section{DOŚWIADCZENIE ZWALCZANIA PRZESTĘPCZOŚCI WŚRÓD MŁODZIEŻY W CZASIE II WOJNY ŚWIATOWEJ LAT 1942-1945}

Streszczenie: Artykuł analizuje tożsamość młodocianego przestępcy, jego cechy społeczne i psychologiczne. Określono społeczne i ekonomiczne przyczyny przestępstw popełnianych przez dzieci. Podano przykłady bezrobocia nieletnich i naruszania porządku publicznego. Ujawniono główne działania rządu radzieckiego w zakresie zapobiegania przestępczości wśród bezdomnych dzieci, poszukiwania dzieci, tworzenia sieci agencji, pracy ideologicznej. Przedstawiono statystyki dotyczące liczby i rodzajów przestępstw popełnianych przez nieletnich, a także ich przykłady. Porównanie przestępczości nieletnich w zachodnich i wschodnich regionach ZSRR oraz jej cechy. W szczególności wysunięto wniosek o skuteczności władz w zapobieganiu i zwalczaniu przestępczości nieletnich w latach 1942-1945.

Słowa kluczowe: dzieci, bezdomność, przestępczość, nieletni, środki zapobiegawcze, poszukiwania

\section{ДОСВІД ПОДОЛАННЯ ЗЛОЧИННОСТІ СЕРЕД НЕПОВНОЛІТНІХ У РОКИ ДРУГОЇ СВІТОВОЇ ВІЙНИ 1942-1945}

Резюме: У статті розглядається особистість неповнолітньої дитини, ії соціальні та психологічні особливості. Визначаються соціальні та економічні причини негативних вчинків, які здійснені дітьми. Наводяться приклади незайнятості неповнолітніх 
та порушення громадського порядку. Розкриваються основні заходи радянської влади у сфері запобігання злочинності серед безпритульних дітей, розшук дітей, створення агентурної мережі, ідеологічної роботи. Наводяться статистичні відомості про кількість та види злочинів які вчинялися неповнолітніми, а також їх приклади. Здійснюється порівняння злочинності неповнолітніх у західних і східних областях УРСР та її особливості. Зокрема, зроблено висновок про ефективність діяльності органів влади, щодо попередження та подолання дитячої злочинності в 1942-1945 pp.

Ключові слова: діти, безпритульність, злочинність, неповнолітні, профілактичні заходи, розшук 